\title{
Uchylenie przepisu prawa przewidującego nieważność decyzji z mocy prawa a możliwość jego dalszego stosowania w zw. z art. 156 § 1 pkt 7 k.p.a.
}

Wyrok Naczelnego Sądu Administracyjnego z dnia 9 stycznia 2019 r., II OSK 1127/17

Przesłanki stwierdzenia nieważności decyzji określone w art. 156 § 1 pkt 1-7 k.p.a. mają charakter rozłączny. Skoro oznaczona wadliwość kwalifikowana decyzji w dacie jej wydania dawała podstawę do stwierdzenia nieważności tej decyzji na podstawie art. 156 § 1 pkt 7 k.p.a., to późniejsze uchylenie przepisu prawa materialnego przewidującego nieważność z mocy prawa takiej decyzji nie uzasadnia zmiany kwalifikacji takiego postępowania jako prowadzonego np. na podstawie art. 156 $\S 1$ pkt 2 k.p.a.

\section{Weronika Szafrańska}

Uniwersytet Śląski

weronika.szafranska@us.edu.pl

ORCID: 0000-0002-6903-8758

https://doi.org/10.26881/gsp.2020.2.16

\section{Glosa}

W uzasadnieniu omawianego w niniejszej publikacji wyroku sąd odniósł się do kilku problematycznych zagadnień, na których skarżący oparli w skardze kasacyjnej swoją argumentację przeciwko wyrokowi wojewódzkiego sądu administracyjnego (WSA). Sąd oddalił w nim skargę strony na decyzję samorządowego kolegium odwoławczego (SKO) stwierdzającą nieważność decyzji ustalającej warunki zabudowy dla inwestycji z uwagi na sprzeczność decyzji z miejscowym planem zagospodarowania przestrzennego.

Po pierwsze, sąd podzielił powszechne w doktrynie i orzecznictwie stanowisko, że zarzut naruszenia art. 145 § 1 pkt 4 k.p.a. ${ }^{2}$ może zostać skutecznie podniesiony jedynie

\footnotetext{
1 Wyrok NSA z dnia 9 stycznia 2019 r., II OSK 1127/17, LEX nr 2645867.

2 Ustawa z dnia 14 czerwca 1960 r. - Kodeks postępowania administracyjnego (tekst jedn.: Dz. U. z 2020 r., poz. 256 ze zm.; dalej: k.p.a.).
} 
przez podmiot pominięty w postępowaniu administracyjnym, nie zaś przez inną biorącą w nim udział stronę postępowania ${ }^{3}$. Po drugie, sąd zwrócił uwagę skarżącym, że zarzut niewłaściwego odczytania treści miejscowego planu zagospodarowania przestrzennego przez organy, nie może być podnoszony jako naruszenie art. 80 k.p.a., tj. przekroczenie swobodnej oceny dowodów. Miejscowy plan zagospodarowania przestrzennego jest aktem złożonym z norm prawa materialnego, i tym samym nie może być postrzegany jako dowód w sprawie, dotyczący okoliczności stanu faktycznego, który można poddawać swobodnej ocenie na podstawie ww. przepisu. Negowanie ustaleń organu, dokonanych na podstawie wykładni miejscowego planu, może następować jedynie w związku z zarzutem błędnej wykładni lub niewłaściwego zastosowania jego przepisów ${ }^{4}$. Po trzecie, sąd odwoławczy zgodził się z argumentacją sądu pierwszej instancji, że na podstawie przepisów ustawy o zagospodarowaniu przestrzennym ${ }^{5}$, w przypadkach gdy planowana inwestycja może oddziaływać na sąsiednie działki, stronami w postępowaniu o wydanie decyzji o ustaleniu warunków zabudowy i zagospodarowania terenu będą także właściciele i użytkownicy wieczyści działek, na które dana inwestycja będzie oddziaływać6.

Niewątpliwie jednak, poza powyższymi rozważaniami zasługującymi na pełną aprobatę, najwięcej uwagi poświęcono w wyroku problematyce stosowania tzw. wady nieważności z mocy przepisów szczególnych, i to właśnie temu zagadnieniu, ze względów objętościowych, zostanie poświęcona niniejsza glosa.

Naczelny Sąd Administracyjny (NSA), uchylając zaskarżony wyrok WSA i zaskarżoną decyzję oraz poprzedzającą ją decyzję SKO w sprawie stwierdzenia nieważności decyzji ustalającej warunki zabudowy dla inwestycji, nie zgodził się ze wskazaną w wyroku sądu pierwszej instancji argumentacją, jakoby decyzja w rażący sposób naruszała prawo, a zatem wypełniała znamiona przesłanki z art. 156 § 1 pkt 2 k.p.a. Zdaniem NSA, zarówno WSA, jak i SKO przeoczyły fakt, że w dacie podejmowania źródłowej decyzji obowiązywał art. 46a ust. 1 pkt 1 oraz 46a ust. 2 u.z.p. z 1994 r., zgodnie z którymi decyzja o warunkach zabudowy i zagospodarowania terenu była nieważna, jeżeli była sprzeczna z ustaleniami miejscowego planu zagospodarowania przestrzennego - stwierdzenie nieważności następowało na zasadach określonych w k.p.a. Jednocześnie skład orzekający zgodził się z prezentowanym w judykaturze poglądem (negując zarazem niektóre głosy prezentowane w piśmiennictwie, o czym mowa niżej), „że skoro w postępowaniu o stwierdzenie nieważności decyzji administracyjnej organ

\footnotetext{
3 Jest to pogląd upowszechniony w orzecznictwie sądów administracyjnych. Oprócz orzeczeń wskazanych w opisywanym wyroku zob. także wyroki NSA z dnia: 29 stycznia 2019 r., II OSK 2040/17, LEX nr 2621917; 10 grudnia 2018 r., II OSK 2941/18, LEX nr 2593898; 15 lutego 2018 r., II OSK 1017/16, LEX nr 2472333; 26 marca 2013 r., II OSK 2276/11, LEX nr 1331889; 15 lutego 2011 r., II OSK 307/10, LEX nr 992540.

4 Zob. wyrok NSA z dnia 11 grudnia 2007 r., II OSK 1651/06, LEX nr 450079 oraz wyrok NSA (oddziału zamiejscowego w Lublinie) z dnia 5 listopada 1993 r., SA/Lu 358/93, LEX nr 1688336.

5 Chodziło o poprzednio obowiązującą ustawę z dnia 7 lipca 1994 r. o zagospodarowaniu przestrzennym (Dz. U. Nr 89, poz. 415 ze zm.; dalej: u.z.p. z 1994 r.).

6 Sąd oparł się w tym wypadku na uchwale składu 5 sędziów NSA z dnia 25 września 1995 r., VI SA 13/95, LEX nr 10650.
} 
administracji orzeka jako organ kasacyjny na podstawie przepisów i stanu faktycznego, obowiązujących w dacie wydania decyzji podlegającej ocenie pod względem istnienia przesłanek do stwierdzenia jej nieważności, późniejsza zmiana przepisów prawa polegająca na utracie mocy obowiązującej ustawy oraz utracie mocy miejscowego planu zagospodarowania przestrzennego, nie ma znaczenia w sprawie (wyrok Naczelnego Sądu Administracyjnego z dnia 29 września 2006 r., II OSK 1174/05)".

Celem niniejszej glosy jest przedstawienie argumentacji popierającej powyższy pogląd NSA.

Zgodnie z art. 156 § 1 pkt 7 k.p.a., organ administracji publicznej stwierdza nieważność decyzji, która zawiera wadę powodującą jej nieważność z mocy prawa.

Przesłanka ta, choć w nieco odmiennym brzmieniu, jest obecna w polskich przepisach już od uchwalenia rozporządzenia Prezydenta Rzeczypospolitej z 1928 r. o postępowaniu administracyjnem ${ }^{7}$. Zgodnie z art. 101 ust. 1 lit. e ww. aktu, władza nadzorcza mogła w trybie nadzoru uchylić z urzędu bądź z własnej inicjatywy, bądź na skutek zażalenia, jako nieważną każdą decyzję, która zawierała wadę powodującą nieważność tej decyzji na mocy wyraźnego przepisu prawa. Treść tę powtórzono w 1960 r., uchwalając kodeks postępowania administracyjnego ${ }^{8}$ - w myśl art. 137 § 1 pkt 7 uchyleniu jako nieważna podlegała decyzja, która zawierała wadę powodującą nieważność tej decyzji na mocy wyraźnego przepisu prawa. Zmiana przepisu nastąpiła wraz z nowelizacją k.p.a. w 1980 r. ${ }^{9}$ Usunięcie doprecyzowania, wedle którego stwierdzenie nieważności następowało tylko wtedy, gdy wada została wyrażona w „wyraźnym przepisie prawa”, i zastąpienie go sformułowaniem o wadzie powodującej nieważność „z mocy prawa" umożliwiło ustawodawcy tworzenie bardziej ogólnych przepisów znajdujących zastosowanie w ramach art. $156 \S 1$ pkt 7 k.p.a. - wada decyzji powodująca nieważność nie musiała już być ściśle dookreślona w odrębnym przepisie, co pozwoliło na tworzenie bardziej ogólnych norm ${ }^{10}$. Zmiana ta spowodowała jednak powstanie przepisów rodzących trudne do usunięcia wątpliwości. Przykładowo, zgodnie z uchylonym ${ }^{11}$ już art. 11 ustawy - Prawo ochrony środowiska ${ }^{12}$ - decyzja wydana z naruszeniem przepisów dotyczących ochrony środowiska była nieważna. Tak ogólne sformułowanie przepisu doprowadziło do wykształcenia w orzecznictwie i doktrynie kilku stanowisk odnoszących się do możliwości jego zastosowania. Od twierdzenia, że ww.

7 Rozporządzenie Prezydenta Rzeczypospolitej z dnia 22 marca 1928 r. o postępowaniu administracyjnem (Dz. U. R.P. Nr 36, poz. 341 ze zm.).

8 Ustawa z dnia 14 czerwca 1960 r. - Kodeks postępowania administracyjnego (Dz. U. Nr 30, poz. 168).

9 Zob. art. 11 pkt 78 ustawy z dnia 31 stycznia 1980 r. o Naczelnym Sądzie Administracyjnym oraz o zmianie ustawy - Kodeks postępowania administracyjnego (Dz. U. Nr 4, poz. 8; akt uchylony).

10 J. Borkowski, B. Adamiak [w:] eidem, Kodeks postępowania administracyjnego. Komentarz, Warszawa 2019, s. 946.

11 Uchylenie nastąpiło na podstawie art. 144 pkt 4 ustawy z dnia 3 października 2008 r. o udostępnianiu informacji o środowisku i jego ochronie, udziale społeczeństwa w ochronie środowiska oraz o ocenach oddziaływania na środowisko (Dz. U. z 2008 r. Nr 199, poz. 1227; tekst jedn.: Dz. U. z 2020 r., poz. 283 ze zm.).

12 Ustawa z dnia 27 kwietnia 2001 r. - Prawo ochrony środowiska (tekst jedn.: Dz. U. z 2019 r., poz. 1396 ze zm.; dalej: p.o.ś.). 
artykuł nie wprowadzał żadnych gradacji wad i każde naruszenie przepisów aktów stanowiących źródła prawa ochrony środowiska prowadziło do stwierdzenia nieważności, poprzez pogląd, że art. 156 § 1 pkt 7 k.p.a. dotyczy tylko wad o większym ciężarze gatunkowym aniżeli przesłanki zawarte w art. $156 \S 1$ pkt 1-6 k.p.a., i tym samym przepisy szczególne stosowane w związku z tym przepisem musiały być wykładane przy poszanowaniu zasady proporcjonalności pomiędzy dobrami chronionymi a skutkami stwierdzenia nieważności. Wreszcie przedstawiciele trzeciego poglądu zrównywali wszystkie podstawy dla stwierdzenia nieważności, wskazując, że każda z siedmiu przesłanek z art. 156 § 1 k.p.a. to w istocie wadliwość polegająca na rażącym naruszeniu prawa i pod tym kątem muszą być także badane wady wskazywane w przepisach szczególnych, znajdujące zastosowanie na podstawie art. $156 \S 1$ pkt 7 k.p.a. ${ }^{13}$

Powyższe problemy interpretacyjne doprowadziły do uchylenia art. 11 p.o.ś. Podobny los spotkał także poddawany interpretacji w opisywanym wyroku art. 46a nieobowiązującej już u.z.p. z 1994 r. Artykuł ten zastąpił od dnia 1 stycznia 1999 r. ${ }^{14}$ artykuły 16 i 34 ww. ustawy. Zgodnie z tymi przepisami, decyzja o warunkach zabudowy i zagospodarowania terenu była nieważna, jeżeli m.in. była sprzeczna z ustaleniami miejscowego planu zagospodarowania przestrzennego. Przepis ten uchylono po niecałych pięciu latach obowiązywania, uchwalając nową ustawę o planowaniu i zagospodarowaniu przestrzennym ${ }^{15}$, a zatem wyżej opisana sankcja nieważności wynikająca z przepisu szczególnego obowiązywała przez prawie dziewięć lat.

Tak jak w przypadku nadmienionego art. 11 p.o.ś., zdaje się, że i w tej sytuacji powodem uchylenia tego przepisu szczególnego były wątpliwości interpretacyjne. Jakkolwiek należy zgodzić się, że skutki, o których mowa w art. 46a ust. 1 u.z.p. z 1994 r., rodziła taka sprzeczność naruszająca lub mogąca naruszyć zasady ładu przestrzennego przewidziane w danym planie miejscowym, niewątpliwie sam stopień naruszenia skutkujący stwierdzeniem nieważności mógł być postrzegany odmiennie przez stosujące przepis organy ${ }^{16}$ - w praktyce mogło pojawiać się zatem tyle interpretacji owej sprzeczności, ile organów drugiej instancji stwierdzających nieważność decyzji.

Należy przypuszczać, że to właśnie rozliczne wątpliwości interpretacyjne rodzące się na tle każdego zawierającego pojęcia nieostre przepisu szczególnego, stanowiącego podstawę dla stwierdzenia nieważności aktu w związku z art. 156 § 1 pkt 7 k.p.a., doprowadziły do prawie całkowitego wyrugowania z systemu prawnego tego rodzaju „dodatkowych", tzn. wykraczających poza art. 156 k.p.a., przesłanek nieważności ${ }^{17}$.

13 Zob. szerzej: B. Majchrzak, Konsekwencje uchylenia art. 11 ustawy - Prawo ochrony środowiska (wybrane uwagi), KPP 2008, nr 3-4, s. 183 i n.

14 Na mocy art. 91 pkt 14 ustawy z dnia 24 lipca 1998 r. o zmianie niektórych ustaw określających kompetencje organów administracji publicznej - w związku z reformą ustrojową państwa (Dz. U. z 1998 r. Nr 106, poz. 668).

15 Zob. art. 88 ustawy z dnia 27 marca 2003 r. o planowaniu i zagospodarowaniu przestrzennym, (Dz. U. z 2003 r. Nr 80, poz. 717).

16 E. Radziszewski, Komentarz do ustawy o zagospodarowaniu przestrzennym, Warszawa 2002, s. 128.

17 R. Hauser, A. Skoczylas, Przesłanki wzruszania ostatecznych decyzji administracyjnych przewidziane w ustawach szczególnych [w:] Instytucje procesu administracyjnego i sq̨dowoadministracyjnego. Księga jubileuszowa dedykowana Prof. nadzw. dr. hab. Ludwikowi Żukowskiemu, red. J. Posłuszny, Z. Czarnik, 
Uchylanie przepisów zawierających tzw. klauzule nieważności powoduje oczywiście niejako „powrót” do stosowania przepisów ogólnych, tj. art. 156 § 1 pkt 1-6 k.p.a., co w niektórych przypadkach może oznaczać wręcz zaostrzenie kryteriów stwierdzenia nieważności - nie wystarczy już bowiem wada uznawana za istotną, pomijając bowiem wady wymienione w przepisie expressis verbis, stwierdzenie nieważności będzie możliwe tylko w sytuacji wady rażąco naruszającej prawo ${ }^{18}$. Oczywiście zasadniczą różnicą po usunięciu klauzuli pozwalającej na stosowanie art. 156 § 1 pkt 7 k.p.a. jest, w większości przypadków, umożliwienie stwierdzenia nieważności decyzji „ponaddziesięcioletniej". Niewątpliwie przesłanką stwierdzenia nieważności, zastępującą uchylone przepisy szczególne, będzie zawarta w art. 156 § 1 pkt 2 k.p.a. przesłanka wydania decyzji z rażącym naruszeniem prawa, zgodnie zaś z $§ 2$ ww. przepisu, przesłanka ta nie została - w przeciwieństwie do stwierdzenia nieważności na mocy przepisów szczególnych - opatrzona dodatkową przesłanką negatywną upływu czasu' ${ }^{19}$.

I to właśnie zastosowanie przesłanek negatywnych, i tym samym stwierdzenie nieważności decyzji bądź tylko stwierdzenie jej wydania z naruszeniem prawa, jest główną konsekwencją rozstrzygnięcia w omawianym wyroku intertemporalnego problemu stosowania uchylonych przepisów szczególnych dla stwierdzania nieważności decyzji.

Sąd w komentowanym wyroku, uwzględniając skargę kasacyjną, stanął na stanowisku, że skoro w postępowaniu o stwierdzenie nieważności decyzji administracyjnej organ administracji orzeka jako organ kasacyjny na podstawie przepisów i stanu faktycznego, obowiązujących w dacie wydania decyzji podlegającej ocenie pod względem istnienia przesłanek do stwierdzenia jej nieważności, późniejsza zmiana przepisów prawa polegająca na utracie mocy obowiązującej przepisu zawierającego pozytywną przesłankę stwierdzenia nieważności, w badanym przypadku art. 46a u.z.p. z 1994 r. (czy to poprzez uchylenie samego przepisu, czy też uchylenie całej ustawy) nie ma znaczenia w sprawie stwierdzenia nieważności. Zdaniem sądu, jeśli w dacie podejmowania decyzji, o której stwierdzenie nieważności zawnioskowano, obowiązywał przepis kwalifikujący oznaczoną wadliwość decyzji jako powodującą jej nieważność z mocy prawa, to uchylenie z porządku prawnego całej ustawy nie usuwa dopuszczalności stosowania tego właśnie przepisu jako kryterium wadliwości źródłowej decyzji.

R. Sawuła, Rzeszów 2009, s. 136. Zob. także A. Matan, Wada nieważności z mocy przepisów szczególnych [w:] System Prawa Administracyjnego Procesowego, t. 2, Weryfikacja rozstrzygnięć w postępowaniu administracyjnym ogólnym, red. B. Adamiak, Warszawa 2019, s. 638-640. W aktualnym brzmieniu p.o.ś., namiastki klauzuli nieważnościowej można dopatrzyć się $w$ art. 212 § 3, zgodnie z którym w przypadku stwierdzenia nieprawidłowości w zakresie wydawania przez starostę pozwoleń zintegrowanych minister właściwy do spraw środowiska kieruje wystąpienie, którego treścią może być w szczególności wniosek o stwierdzenie nieważności decyzji w przedmiocie wydania pozwolenia zintegrowanego. Klauzulę tę zawiera także m.in. ustawa z dnia 20 lipca 2018 r. - Prawo o szkolnictwie wyższym i nauce (Dz. U. z 2018 r., poz. 1668 ze zm.) w art. 77 ust. 5, art. 195 oraz art. 225.

18 Por. B. Majchrzak, Konsekwencje uchylenia..., s. 187.

19 Ze względów objętościowych autorka pomija w tym miejscu rozważania prowadzone w związku z wyrokiem TK z dnia 12 maja 2015 r., P 46/13, odsyłając w tym aspekcie m.in. do M. Wiącek, Stosowanie Konstytucji przez sqdy administracyjne. Glosa do wyroku Naczelnego Sądu Administracyjnego z dnia 20 lutego 2019 r., Il OSK 694/17, OSP 2019, nr 9, s. 165 i n.; J. Trzciński, Glosa do wyroku NSA z dnia 20 lutego 2019 r., Il OSK 694/17, ZNSA 2019, z. 3, s. 137 i n. 
W konsekwencji, skoro wydanie decyzji o warunkach zabudowy i zagospodarowania terenu nastąpiło w okresie obowiązywania art. 46 a ust. 1 pkt 1 u.z.p., a decyzja w chwili wydania wypełniała znamiona uznania jej na podstawie tego przepisu za nieważną, to kwalifikacja taka, tj. z art. 156 § 1 pkt 7 k.p.a., musi być nadal stosowana i nie można zastąpić jej kwalifikacją z art. 156 § 1 pkt 2 k.p.a., na podstawie której wydano zaskarżoną decyzję o stwierdzeniu nieważności. Przyjęcie takiego poglądu pociąga za sobą, o czym wspomniano wyżej, konieczność zastosowania art. 156 § 2 k.p.a. i uwzględnienie przesłanki negatywnej uniemożliwiającej stwierdzenie nieważności decyzji po upływie dziesięciu lat od jej wydania.

Powyższy - przyjęty przez skład orzekający - pogląd stoi w sprzeczności z wyrażanym niekiedy w literaturze, a także i niektórych orzeczeniach sądów administracyjnych, stanowiskiem, jakoby przepis szczególny statuujący klauzulę nieważności nie mógł być stosowany po jego uchyleniu, nawet w odniesieniu do decyzji wydanych w trakcie jego obowiązywania ${ }^{20}$. Reprezentujący to stanowisko opierają je na dwóch zasadniczych argumentach. Po pierwsze, jak wskazuje Krzysztof Kaszubowski, należy odróżnić kwestię stwierdzenia wadliwości od kwalifikacji tej wadliwości i podstawy prawnej ku temu. Autor ten jest zdania, że stwierdzenie, iż decyzja jest dotknięta jedną z wad wskazanych w art. $156 \S 1$ k.p.a., rodzi konieczność dokonania kwalifikacji tej okoliczności w odniesieniu do stanu prawnego obowiązującego w chwili orzekania o stwierdzeniu nieważności, bowiem tylko takie rozwiązanie czyni zadość obowiązującej organy w chwili orzekania zasadzie praworządności, zgodnie z którą organy muszą działać na podstawie przepisów obowiązujących w chwili orzekania. O ile zatem w postępowaniu o stwierdzenie nieważności badamy, czy dana decyzja w chwili jej wydania naruszała obowiązujące wówczas przepisy, o tyle konsekwencje tegoż naruszenia muszą być oceniane, zdaniem ww. Autora, według stanu prawnego istniejącego w momencie rozstrzygania o nieważności ${ }^{21}$. Podobnie WSA we Wrocławiu wykazał w jednym z orzeczeń22, że art. $156 \S 1$ pkt 7 k.p.a. jako przepis niesamodzielny zakłada istnienie w porządku prawnym wyraźnej normy przewidującej nieważność decyzji i w przeciwieństwie do przesłanki z pkt 2 art. 156 § 1 k.p.a. - zawarta w nim przesłanka jest związana z datą orzekania o nieważności. Sąd oparł swój pogląd na wykładni językowej (konkretnie gramatycznej) przepisu, wskazując na zastosowany w przepisie art. 156 § 1 pkt 7 k.p.a. czas teraźniejszy „zawiera” - czyli: posiada obecnie - „wadę powodującą jej nieważność z mocy prawa” - czyli: niepowodującą niegdyś, lecz w tej chwili - i zestawiając go z użytym w art. $156 \S 1$ pkt 2 k.p.a. czasem przeszłym:„decyzja, która wydana została z rażącym naruszeniem prawa”. Dalej sąd wskazał, że: „Nie można więc treści skutków decyzji o stwierdzeniu nieważności (skutki wsteczne) odnosić do

20 Tak m.in. K. Kaszubowski [w:] idem, M. Szałkiewicz, Problem podstawy prawnej orzekania w postępowaniu o stwierdzenie nieważności decyzji administracyjnej. Dwugłos w sprawie, Casus 2011, nr 62, s. 27 i n. Z poglądem tym zgadza się T. Kiełkowski - zob. idem [w:] Kodeks postępowania administracyjnego. Komentarz, red. H. Knysiak-Molczyk, Warszawa 2019, s. 1088-1089; por. także M. Jaśkowska [w:] eadem, A. Wróbel, Kodeks postępowania administracyjnego. Komentarz, Warszawa 2018, s. 1092.

21 K. Kaszubowski, Problem podstawy prawnej..., s. 27-28.

22 Wyrok WSA we Wrocławiu z dnia 5 grudnia 2012 r., II SA/Wr 647/12, LEX nr 1387580. 
podstawy stwierdzenia nieważności decyzji »z mocy prawa«. Należy wnosić, że z określonych, racjonalnych przyczyn ustawodawca eliminuje z porządku prawnego określenie takiej wady decyzji, która wywołuje jej nieważność z mocy prawa. Istnienie tej wadliwości nie powinno być przedłużane przez organ wbrew ustawie jedynie dlatego, że nadal istnieje ogólna (art. 156 § 1 pkt 7 k.p.a.) podstawa do orzekania o takim skutku danej wady. Nie zmienia to przecież i w żadnym zakresie nie dotyczy możności rozpatrywania podstawy rażącego naruszenia prawa".

Pomimo przedstawionych argumentów, autorka jest zdania, że na aprobatę zasługuje pogląd wyrażony w opisywanym w niniejszej glosie orzeczeniu.

Po pierwsze, choć należy zgodzić się z poglądem, że konsekwencje naruszenia prawa muszą być oceniane według stanu prawnego istniejącego w momencie rozstrzygania o nieważności, trzeba wskazać, że pogląd ten powinno się odnosić do konsekwencji, jaką jest sama możliwość stwierdzenia nieważności decyzji (aktu administracyjnego) na podstawie przesłanki pozytywnej zawartej w art. 156 § 1 k.p.a., obowiązującej w momencie stwierdzania nieważności. W chwili rozstrzygania o nieważności musi bowiem obowiązywać przesłanka pozytywna ujęta w ustawie procesowej (w art. 156 § 1 k.p.a.), która w ogóle umożliwia zastosowanie trybu stwierdzenia nieważności względem danego aktu administracyjnego. Gdyby bowiem nie istnienie przesłanki zawartej w art. 156 § 1 pkt 7, to zastosowanie znanej polskiemu ustawodawstwu instytucji względnego stwierdzenia nieważności na podstawie samego art. 46a u.z.p. z 1994 r. (jak i na przykład uchylonego po zmianie art. 11 p.o.ś.) byłyby niemożliwe. Brak przepisu art. 156 § 7 k.p.a. oznaczałby, że wspominany wyżej art. 46a u.z.p. z 1994 r. wprowadzałby de facto instytucję nieważności bezwzględnej, nieznaną polskim przepisom prawa administracyjnego i uznawaną za niemożliwą do stosowania w polskim systemie prawnym ze względu na chaos, który niosłoby ze sobą przyjęcie tego sposobu określania nieważności aktu. Z tego względu można przyjąć, że stosowanie przesłanki nieważności z mocy prawa ma w istocie charakter dwuskładnikowy - skoro przepis szczególny materialny nie mógłby zostać zastosowany bez uregulowania zawartego w art. 156 § 1 pkt 7 k.p.a., to właśnie istnienie poszczególnych przesłanek ujętych w art. $156 \S 1$ k.p.a. powinno być oceniane przez organ pod kątem istnienia w momencie stwierdzania nieważności aktu²3.

Jeśli zatem przepis art. 156 § 1 pkt 7 k.p.a. obowiązuje, istnieje możliwość stwierdzania nieważności w oparciu o tzw. klauzule nieważnościowe zawarte w przepisach szczególnych. Samo istnienie przepisu szczególnego jest już zaś ściśle związane z decyzjami wydawanymi w czasie jego obowiązywania. Jeżeli nie budzi wątpliwości, że dla oceny przyczyn stwierdzenia nieważności decyzji punktem odniesienia jest stan faktyczny i prawny z chwili jej podjęcia ${ }^{24}$, przepis szczególny statuujący daną wadę nieważnościową musi być zaliczany do owego „stanu prawnego” z chwili wydawania decyzji będącej przedmiotem postępowania nieważnościowego. Takie rozumowanie można uznać także za pochodną zasad pewności prawa czy ochrony praw nabytych,

23 Zob. wyrok NSA z dnia 21 stycznia 1988 r., IV SA 941/87, LEX nr 9986.

24 T. Kiełkowski [w:] Kodeks postępowania..., s. 1074. 
które mogą być respektowane tylko w przypadku, gdy do zdarzeń prawnych będziemy stosować przepisy prawa materialnego, obowiązujące w dacie ich zaistnienia. Zdarzeniem prawnym na gruncie trybu nieważnościowego byłoby wydanie decyzji będącej przedmiotem tego postępowania, podlegającej kontroli w postępowaniu nadzwyczajnym, bowiem stwierdzenie nieważności następuje ze skutkiem ex tunc.

Przyjęcie poglądu przeciwnego mogłoby doprowadzić do występowania niebezpiecznych precedensów w praktyce organów. Można bowiem wyobrazić sobie sytuację, w której ustawodawca uchwaliłby przepis szczególny będący klauzulą nieważnościową stosowaną w zW. z art. 156 § 7 k.p.a., którego zastosowanie, przy przyjęciu poglądu o ocenie wady nieważnościowej na mocy przepisu szczególnego $w$ dacie rozstrzygania o nieważności, doprowadziłoby tym samym do stwierdzania nieważności decyzji, która w dniu jej wydania była w istocie prawidłowa, bowiem klauzula nieważnościowa jeszcze wtedy nie istniała (nie obowiązywała).

Oczywiście, choć ustawodawca powinien wprowadzać tego typu zmiany, uwzględniając skutki wynikające z zasady lex retro non agit, nie można przyją́ z całą pewnością, że w niektórych przypadkach, w trakcie procesu legislacyjnego nie umknęłyby mu pewne dalej idące skutki wprowadzanych regulacji. A contrario, przyjęcie poglądu, zgodnie z którym przesłanka stwierdzenia nieważności decyzji określona w przepisie szczególnym (w zw. z art. 156 \$ pkt 7 k.p.a.) jest stosowana także wówczas, gdy przepis szczególny stanowiący podstawę nieważności decyzji z mocy prawa, utracił moc obowiązującą po wydaniu decyzji, oznacza zarazem, że ustawodawca, wprowadzając nowe klauzule nieważnościowe stosowane w zw. $z$ art. 156 \$ 1 pkt 7 k.p.a., nie musiałby poddawać tych zmian ocenie pod kątem naruszania zasady lex retro non agit - na tej podstawie można bowiem stwierdzać nieważność decyzji tylko w sytuacjach, gdy zostały one wydane w czasie obowiązywania przepisów szczególnych, regulujących nieważność decyzji z mocy prawa.

Pogląd ten uznają także Roman Hauser z Andrzejem Skoczylasem, którzy zgadzają się z wyrażonym w orzecznictwie sądów administracyjnych stanowiskiem, że ocena zgodności z prawem decyzji wydanej w postępowaniu w trybie zwykłym musi być przeprowadzona w świetle przepisów obowiązujących w chwili wydawania owej decyzji w trybie zwykłym, zaś fakt utraty mocy obowiązującej przepisu szczególnego nie ma i nie może mieć żadnego wpływu na ocenę zgodności z prawem decyzji podjętej w czasie jego obowiązywania ${ }^{25}$. Jak wskazano także w cytowanym przez wyżej wymienionych wyroku, „okoliczność, że po jej wydaniu [decyzji - przyp. W.S.] zmienił się stan prawny i z punktu widzenia owego zmienionego stanu prawnego trzeba by uznać, (...) że utracił moc obowiązującą przepis szczególny, który kwalifikował decyzję jako nieważną, nie może mieć żadnego wpływu na ocenę zgodności z prawem zaskarżonej decyzji i na to, iż trzeba będzie stwierdzić nieważność tej decyzji na podstawie art. 156 $\S 1$ pkt 2 (pkt 7) k.p.a. Decydować musi bowiem stan prawny z chwili podejmowania decyzji w trybie zwyczajnym. Inną sprawą jest to, że rozpatrując sprawę merytorycznie

25 R. Hauser, A. Skoczylas, Przesłanki wzruszania..., s. 136-137. Tak też J. Borkowski, Zmiana i uchylanie ostatecznych decyzji administracyjnych, Warszawa 1967, s. 140. 
w wyniku stwierdzenia nieważności dotychczasowej decyzji organ administracji będzie orzekał według nowego stanu prawnego - obowiązującego w chwili podejmowania nowego rozstrzygnięcia" ${ }^{\prime 26}$.

Po drugie, choć rację ma sąd wskazujący w jednym z orzeczeń, że należy wnosić, iż ustawodawca eliminuje z porządku prawnego przepisy określające wady decyzji wywołujące nieważność z mocy prawa z pobudek racjonalnych ${ }^{27}$, można przypuszczać, że w wielu wypadkach powodem dla ich uchylania jest po prostu problem z ich interpretacją. Jakkolwiek WSA we Wrocławiu wskazał w ww. wyroku (opowiadając się przeciw tezie niniejszej glosy i omawianego wyroku NSA), że „istnienie tej wadliwości [klauzuli nieważnościowej - przyp. W.S.] nie powinno być przedłużane przez organ [przez stosowanie w trybie nadzwyczajnym - przyp. W.S.] wbrew ustawie jedynie dlatego, że nadal istnieje ogólna (art. 156 § 1 pkt 7 k.p.a.) podstawa do orzekania o takim skutku danej wady", zdaje się, że nie należy traktować stosowania uchylonego przepisu - klauzuli nieważności - w ramach trybu nadzwyczajnego, jako „przedłużania istnienia wadliwości". Tryby nadzwyczajne to tryby, jak wskazuje sama nazwa, wszczynane w szczególnych przypadkach, a organy stosują w ich ramach uchylone przepisy szczególne wprowadzające nieważność z mocy prawa w zw. z art. 156 § pkt 7 k.p.a. jedynie wyjątkowo, a zatem stwierdzenie o przedłużaniu istnienia wadliwości zdaje się zbyt kategoryczne. Ustawodawca osiągnął swój cel, uchylając klauzulę nieważnościową: uchylony przepis nie obowiązuje, jest on stosowany wyjątkowo, służąc jedynie ocenie występowania wad kwalifikowanych decyzji wydanych w trakcie jego obowiązywania.

Po trzecie, jakkolwiek argument z wykładni językowej mógłby zostać uznany za przekonujący, należy zauważyć, że użycie $w$ tej przesłance czasu przeszłego, jak w przypadku przesłanek poprzedzających, mogłoby wprowadzić problemy interpretacyjne, bowiem równie dobrze można by wówczas twierdzić, że przepis ten obejmuje jedynie sytuacje, gdy decyzja już takowej wady nie zawiera. Stosując czas teraźniejszy, ustawodawca nie brał zapewne pod uwagę sytuacji, w których dane przepisy będą uchylane, a chciał przede wszystkim zaakcentować możliwość wprowadzania przez przepisy szczególne „dodatkowych" przesłanek nieważności. Zastosowanie w pozostałych przesłankach czasu teraźniejszego byłoby z kolei językowo nielogiczne - przesłanki te musiały zostać przez ustawodawcę utworzone z wykorzystaniem czasownika w aspekcie dokonanym, w czasie przeszłym, w stronie biernej - gdyż każdy inny czas, strona czy użycie czasownika $w$ aspekcie niedokonanym czyniłyby te przesłanki niezrozumiałymi (zamiast „została wydana":,,jest wydana”,,,jest wydawana”,,,zostaje wydana", itp. zmieniałyby całkowicie sens przepisu). Argument z wykładni językowej należy zatem uznać za chybiony.

\footnotetext{
26 Wyrok NSA z dnia 23 października 2008 r., II OSK 1301/07, LEX nr 1012267; zob. także wyrok WSA w Gorzowie Wielkopolskim z dnia 26 sierpnia 2010 r., II SA/Go 387/10, LEX nr 753017.

27 Wyrok WSA we Wrocławiu z dnia 5 grudnia 2012 r., II SA/Wr 647/12, LEX nr 1387580.
} 
Jednocześnie należy zgodzić się z końcowym poglądem wskazanym w komentowanym orzeczeniu ${ }^{28}$, zgodnie z którym zastosowanie art. 156 § 2 k.p.a. w zw. z art. 156 $\S 1$ pkt 7 k.p.a. wyklucza stosowanie art. 156 \$ 1 pkt 2 in fine k.p.a., a wady decyzji wyliczone wyczerpująco $w$ art. $156 \S 1$ pkt 1-6 k.p.a. (szczególnie wada rażącego naruszenia prawa) oraz wada nieważności ustanowiona w przepisach odrębnych są to wady, które się wzajemnie wykluczają ${ }^{29}$. Wszystkie przesłanki zawarte w art. 156 § 1 k.p.a., a także utworzone przez ustawodawcę na mocy przepisów szczególnych w zw. z art. $156 \S 1$ pkt 7 k.p.a., muszą być traktowane rozłącznie.

Za takim poglądem przemawia, po pierwsze - wykładnia systemowa przepisów traktujących o trybach nadzwyczajnych - w przeciwnym wypadku otwarta byłaby bowiem droga do uznawania praktycznie każdej wady kwalifikowanej (także tych wymienionych w innych punktach aniżeli art. $156 \S 1$ pkt 2 in fine k.p.a.) za rażące naruszenie prawa, co oznaczałoby w zasadzie pełną dowolność w kwalifikacji danej wady przez organ, a to byłoby zarazem nie do pogodzenia z różnymi terminami przedawnienia ustanowionymi w art. $156 \S 2$ k.p.a. dla poszczególnych przesłanek.

Należy przyjąć, że ustawodawca świadomie, obok kwalifikowanych wad nazwanych (zawartych w art. 156 § 1 pkt 1 i 2 ab initio oraz art. 156 § 1 pkt 3-6 k.p.a.) oraz wad wynikających z przepisów szczególnych stosowanych w zw. z art. 156 § 1 pkt 7 k.p.a., mających przeważnie także charakter rażący, ustanowił przesłankę ogólną rażącego naruszenia prawa w art. 156 § 1 pkt 2 in fine k.p.a., mieszczącą w swym zakresie niedookreślony katalog pozostałych kwalifikowanych wad decyzji administracyjnych $^{30}$. Stanowisko to jest podzielane w literaturze, w której wskazuje się, że rażące naruszenie prawa jest „punktem ogólnym”, obejmującym wszystkie pozostałe przypadki ciężkiego naruszenia prawa, których nie można zakwalifikować do pozostałych punktów art. 156 § 1 k.p.a. ${ }^{31}$ Co za tym idzie - kierując się wskazówkami logicznymi, należy uznać, że przesłanka rażącego naruszenia prawa znajduje zastosowanie w innych przypadkach, aniżeli wymienione w pozostałych przesłankach - należy wykluczyć z zakresu jej stosowania pozostałe wady nazwane, w tym wszystkie te przesłanki, które stosuje się w zw. z art. 156 § 1 pkt 7 k.p.a. Zdecydowanie w tej kwestii wypowiedziała się m.in. Ewa Śladkowska, trafnie ujmując, że "(...) zasady logiki wymagają, by tego samego uchybienia prawa nie kwalifikować jako różne wadliwości. Szczególnie dotyczy to przesłanki rażącego naruszenia prawa, ponieważ wszystkie naruszenia prawa uzasadniające nieważność decyzji [a więc i w tym także wynikające z przepisów szczególnych i stosowane w zw. z art. $156 \S 1$ pkt 7 k.p.a. - przyp. W.S.] mają charakter rażący. Wszystkie godzą w elementy materialnego stosunku administracyjnego. Stosunek ten w sytuacji, gdy decyzja jest wadliwa, nie może zostać prawidłowo ukształtowany.

28 A także m.in. w wyroku NSA z dnia 23 maja 2019 r., II OSK 1692/17, LEX nr 2682405. Zob. także E. Śladkowska, Wydanie decyzji administracyjnej bez podstawy prawnej lub z rażącym naruszeniem prawa w ogólnym postępowaniu administracyjnym, Warszawa 2013, s. 112.

29 Odmiennie - zob. wyrok NSA z dnia 5 października 2011 r., II OSK 1281/2010, LEX nr 1151835.

30 E. Śladkowska, Wydanie decyzji..., s. 112, s. 221-224.

31 J. Świątkiewicz, Stabilność decyzji administracyjnej, Warszawa 1981, s. 25. 
Należy zatem wyeliminować możliwość kwalifikowania tego samego naruszenia prawa jako wypełniającego znamiona dwóch różnych przesłanek"132.

Po drugie, należy z całą mocą podkreślić, choć zostało to zasygnalizowane już wyżej, że nie można oczekiwać, że racjonalny ustawodawca dookreśliłby inne terminy przedawnienia w art. 156 § 2 k.p.a., gdyby zarazem uważał, że poszczególne wady mogą być zaliczane dowolnie do różnych kategorii przesłanek, co uwidacznia się szczególnie w przypadku zestawienia braku terminu przedawnienia dla przesłanki rażącego naruszenia prawa oraz ustanowienia dziesięcioletniego okresu w sytuacji zastosowania przepisu szczególnego w zw. z art. 156 § 1 pkt 7 k.p.a.

Przedstawione w niniejszej glosie argumenty jednoznacznie wskazują na aprobatę autorki dla podjętego przez NSA w komentowanym wyroku rozstrzygnięcia i jego uzasadnienia.

\section{Literatura}

Borkowski J., Adamiak B. [w:] Kodeks postępowania administracyjnego. Komentarz, Warszawa 2019.

Borkowski J., Zmiana i uchylanie ostatecznych decyzji administracyjnych, Warszawa 1967.

Hauser R., Skoczylas A., Przesłanki wzruszania ostatecznych decyzji administracyjnych przewidziane w ustawach szczególnych [w:] Instytucje procesu administracyjnego i sqdowoadministracyjnego. Księga jubileuszowa dedykowana Prof. nadzw. dr. hab. Ludwikowi Żukowskiemu, red. J. Posłuszny, Z. Czarnik, R. Sawuła, Rzeszów 2009.

Jaśkowska M. [w:] eadem, A. Wróbel, Kodeks postępowania administracyjnego. Komentarz, Warszawa 2018.

Kaszubowski K., Szałkiewicz M., Problem podstawy prawnej orzekania w postępowaniu o stwierdzenie nieważności decyzji administracyjnej. Dwugłos w sprawie, "Casus” 2011, nr 62, s. 25 i n.

Kiełkowski T. [w:] Kodeks postępowania administracyjnego. Komentarz, red. H. Knysiak-Molczyk, Warszawa 2019.

Majchrzak B., Konsekwencje uchylenia art. 11 ustawy - Prawo ochrony środowiska (wybrane uwagi), ,Kwartalnik Prawa Prywatnego" 2008, nr 3-4, s. 179 i.

Matan A., Wada nieważności z mocy przepisów szczególnych [w:] System Prawa Administracyjnego Procesowego, t. 2, Weryfikacja rozstrzygnięć w postępowaniu administracyjnym ogólnym, red. B. Adamiak, Warszawa 2019.

Radziszewski E., Komentarz do ustawy o zagospodarowaniu przestrzennym, Warszawa 2002.

Śladkowska E., Wydanie decyzji administracyjnej bez podstawy prawnej lub z rażącym naruszeniem prawa w ogólnym postępowaniu administracyjnym, Warszawa 2013.

Świątkiewicz J., Stabilność decyzji administracyjnej, Warszawa 1981.

Trzciński J., Glosa do wyroku NSA z dnia 20 lutego 2019 r., II OSK 694/17, "Zeszyty Naukowe Sądownictwa Administracyjnego" 2019, z. 3, s. 137 i n.

Wiącek M., Stosowanie Konstytucji przez sądy administracyjne. Glosa do wyroku Naczelnego Sądu Administracyjnego z dnia 20 lutego 2019 r., II OSK 694/17, ,"Orzecznictwo Sądów Polskich" 2019, z. 9 , s. 165 in.

32 E. Śladkowska, Wydanie decyzji..., s. 112. 


\section{Streszczenie}

\section{Weronika Szafrańska}

Uchylenie przepisu prawa przewidującego nieważność decyzji z mocy prawa a możliwość jego dalszego stosowania w zw. z art. 156 § 1 pkt 7 k.p.a.

Glosa aprobująca do wyroku Naczelnego Sądu Administracyjnego z dnia 9 stycznia 2019 r., II OSK 1127/17 poszerza przedstawioną w uzasadnieniu ww. orzeczenia argumentację przemawiającą za uznaniem, że przepisy szczególne prawa materialnego, stanowiące tzw. klauzule nieważności, pomimo ich późniejszego uchylenia, muszą być brane pod uwagę podczas postępowania w sprawie stwierdzenia nieważności decyzji wydanej w czasie ich obowiązywania, prowadzonego na podstawie art. $156 \S 1$ pkt 7 k.p.a. Autorka przytoczyła w glosie stanowiska przeciwne powyższemu poglądowi, wyrażane w niektórych orzeczeniach sądów administracyjnych oraz literaturze, negując jednocześnie ich prawidłowość.

\section{Summary}

\section{Weronika Szafrańska}

Repeal of the regulation providing the invalidity of a decision by virtue of law and the possibility of the further use of the regulation in question in connection with art. $156 \S 1$ p. 7 of the Code of Administrative Procedure

The commentary approves the judgement of the Supreme Administrative Court of 9 January 2019, II OSK 1127/17 and extends the reasoning provided there. She present arguments supporting the recognition that specific substantive provisions constituting the so-called invalidity clauses despite their subsequent annulment shall be taken into consideration during the procedure for annulment of the decision issued during their validity, based on art. $156 \S 1$ p. 7 of the Code of Administrative Procedure. The author also refers to opposite opinions expressed in some ruling of administrative courts and literature, denying their correctness.

Słowa kluczowe: klauzule nieważności, art. 156 § 1 pkt 7 k.p.a., stwierdzenie nieważności decyzji z mocy prawa

Keywords: invalidity clauses, art. $156 \S 1$ p. 7 of the Code of Administrative Procedure, invalidity of a decision by virtue of law 